\title{
Ortaokul öğrencilerinin kullandığı argo kelimeler çerçevesinden dil ahlakına genel bir bakış
}

Neslihan KARAKUŞ ${ }^{1}$

Mehmet Önder KARACAOĞLU 2

Murat KETEN3

\begin{abstract}
APA: Karakuş, N.; Karacaoğlu, M. Ö.; Keten, M. (2020). Ortaokul öğrencilerinin kullandığı argo kelimeler çerçevesinden dil ahlakına genel bir bakıș. RumeliDE Dil ve Edebiyat Araştırmaları Dergisi, (Ö7), 172-191. DOI: 10.29000/rumelide.808340.
\end{abstract}

\section{Öz}

İnsanın doğuştan getirdiği ya da sonradan kazandığı bir takım tutum ve davranışların tümü olarak tanımlanan ahlak; insanların yaşadıkları topluma uyum sağlamaları ve toplumun huzuru için belirlenmiş kurallar bütünü olarak düşünülebilir. Toplumdan topluma değişebilecek olan bu ahlak kuralları, zamandan zamana göre de değişim arz etmektedir. Diller bu değişimden nasibini almakta ve ahlak kuralları gibi dil kuralları da değişim göstermektedir. Ahlak kavramı ile yola çıkılan çalışmada, dil ahlakı üzerinde durulacak ve ortaokul öğrencilerinin günlük Türkçeyi kullandıkları akran konuşmaları esnasında ne tür argo ve benzeri kelimeler tercih ettiklerinin tespiti yapılmaya çalışılacaktır. Durum tespiti yapıldıktan sonra konu ile ilgili öğretmen görüşleri alınmış ve öğretmenlerin okulda öğrencilerinden duydukları argo içerikli kelimelerin tespiti ile çalışmaya devam edilmiştir. Toplanan verilere öğrencilerin görüşleri de eklenerek çalışma küçük bir saha araştırmasına dönmüştür. Böylelikle öğrencilerden elde edilen veriler de çalışmaya dahil edilmiştir. Yarı yapılandırılmış görüşme formu ile öğretmen ve öğrencilerden toplanan veriler analiz edilmiştir. Çalışmanın bir diğer önemli basamağı da öğrencilerin argo kullanımına etki eden video içerikleri belirlenmesi ve bu videoların içerik analizi ile çözümlenmesi basamağıdır. Araştırma, nitel yöntemle desenlenen bir çalışmadır. Çalışmanın örneklemini Trabzon ilinde resmî bir ortaokulda 6 . ve 7. sınıfta eğitim gören 160 öğrenci oluşturmaktadır. Öğretmen görüşleri ise Türkiye genelinde muhtelif devlet okullarında görev yapan 15 Türkçe öğretmeninden elde edilmiş ve öğretmenlerin tespitleri ile öğrencilerin aktardıkları kıyaslanmıştır. Öğrencilerin kendi aralarında kullandıkları argo ve türevi kelimelerin öğretmenlerden elde edilenlerle örtüştüğü fakat öğretmenlerin bildiğinden çok daha fazla olduğu elde edilen sonuçlar arasındadır. Araştırmanın sebepleri irdelendirken genel anlamda internet kullanımının özel anlamda ise Youtube videolarının bu duruma etkisi tespit edilmiştir. Araştırmanın öğrenci merkezli olarak yürütülen kısmında tespit edilen sözcükler/sözcük grupları ile bu içeriklerde yer alanların birbirleriyle olan benzerliği bu duruma yol açan durumların açık bir göstergesidir.

Anahtar kelimeler: Dil, ahlak, eğitim, Türkçe, argo, ortaokul öğrencileri

\footnotetext{
1 Doç. Dr., Yıldız Teknik Üniversitesi, Eğitim Fakültesi, Türkçe ve Sosyal Bilimler Eğitimi, Türkçe Eğitimi ABD (İstanbul, Türkiye), neslihankarakush@gmail.com, ORCID ID: oooo-0001-7808-1099 [Makale kayıt tarihi: 21.08.2020-kabul tarihi: 20.10.2020; DOI: 10.29000/rumelide.808340]

2 Doktora öğrencisi, MEB Türkçe Öğretmeni, Yıldız Teknik Üniversitesi, Sosyal Bilimler Enstitüsü, Türkçe ve Sosyal Bilimler Eğitimi Doktora Programı (İstanbul, Türkiye), mehmetonder25@gmail.com, ORCID ID: 0000-0002-44616021

3 YL öğrencisi, Yıldız Teknik Üniversitesi, Sosyal Bilimler Enstitüsü, Türkçe Eğitimi Tezsiz Yüksek Lisans Programı (İstanbul, Türkiye), muradketen@gmail.com, ORCID ID: 0000-0003-1129-0966
} 


\title{
An overview of language ethics from the slang words framework used by secondary school students
}

\begin{abstract}
Morality, which is defined as all of the attitudes and behaviors brought by humans or acquired afterwards; It can be considered as a set of rules determined for people's adaptation to the society they live in and the peace of the society. These moral rules, which can change from society to society, also change from time to time. Languages get their share from this change, and language rules also change, just like moral codes. In the study, which is based on the concept of morality, language morality will be focused on and it will be tried to determine what kind of slang and similar words preferred by middle school students during their peer conversations in which they use Turkish daily. After the due diligence, teachers' opinions on the subject were taken and the study continued with the identification of the slang words that teachers heard from their students at school. Adding students' views to the collected data, the study turned into a small field study. Thus, the data obtained from the students were also included in the study. Data collected from teachers and students were analyzed using a semi-structured interview form. Another important step of the study is the determination of video content that affects students' use of slang and the analysis of these videos with content analysis. The research is a study designed with a qualitative method. The sample of the study consists of 160 students studying in the 6 th and 7 th grade at an official secondary school in Trabzon. Teachers' opinions are compared is derived from 15 Turkish teachers working in various public schools across Turkey and they communicated with the students identify the teacher. It is among the results that the slang and derivative words used by the students among themselves overlap with the ones obtained from the teachers but are much more than the teachers know. While examining the reasons of the research, the effect of internet usage in general and Youtube videos in particular was determined. The similarities between the words/phrases identified in the student-centered part of the study and those in these contents are a clear indicator of the situations that led to this situation.
\end{abstract}

Keywords: Language, ethics, education, Turkish, slang, middle school students

\section{Giriş}

Genel anlamda insanın doğuştan getirdiği ya da sonradan kazandığı bir takım tutum ve davranışların tümü olarak tanımlanan ahlak; insanların yaşadıkları topluma uyum sağlamaları ve toplumun huzuru için belirlenmiş kurallar bütünü olarak düşünülebilir. Toplumdan topluma değişebilecek olan bu ahlak kuralları, zamandan zamana göre de değişim arz etmektedir. Diller bu değişimden nasibini almakta ve ahlak kuralları gibi dil kuralları da değişim göstermektedir. Ahlak kavramı ile yola çıkılan çalışmada, dil ahlakı üzerinde durulacak ve ortaokul öğrencilerinin günlük Türkçeyi kullandıkları akran konuşmaları esnasında ne tür argo ve benzeri kelimeler tercih ettiklerinin tespiti yapılmaya çalışılacaktır. Dil, düşüncenin aynasıdır. Hatta Wittgenstein "dilimin sinırları, dünyamın sınırlarıdır." diyerek bu yansımayı daha geniş bir perspektifle ele alır (2012: 5). Düşünce dünyası ne kadar temiz ve berraksa dile yansıyan kelimelerin de o ölçüde temiz olduğu düşünülmektedir.

- 21. yüzyıl becerileri ile donanmış ve "z kuşağı" gibi değişik adlandırmalarla tasvir edilen yeni nesil öğrencilerinin zihinleri bu temizliği yansıtmakta mıdır?

- Dillerinin sınırları, dünyalarının da sınırları mıdır? 
- Son zamanlarda gittikçe normalleşen argo ve hakaret içeren kelimeleri kullanmak öğrencilere neden bu kadar cazip gelmektedir?

- Bu tür kelimelerle birbirlerine hitap etmeleri sadece hazır cevaplık olarak nitelendirilebilir mi?

- İnternetin ve sosyal medyanın bu dil kullanımında etkisi var mı?

\subsection{Dil ve ahlak kavramlarına genel bakış}

İletişimin temeli dildir. En genel tanımla dil "insanlarm düşündüklerini ve duyduklarmı bildirmek için kelimelerle veya işaretlerle yaptıkları anlaşma, lisan, zeban" (Türkçe Sözlük, 526) olarak ifade edilmektedir. Başka bir tanımla da "dil, bizzat insanı "insan" yapan en temel değer ve varlık şartıdır." (Hocaoğlu, 2007: 6). Öyleyse dil insanın sadece iletişim kurduğu bir araç değil aynı zamanda da onu diğer canlılardan ayıran en temel özelliktir. İnsanoğlu bu hasletle kendini ifade etmekte ve insanî ilişkilerinde çizdiği genel bir çerçeve ile dilinin değer yargılarını belirlemektedir. Arapça “خلاق" kökenli ahlak sözcüğü ise çoğul anlam taşımakla birlikte huy, karakter, hal, tabiat ve hareket tarzı gibi mânâlara gelmektedir. Ahlak dilimizde "bir toplum içinde kişilerin uymak zorunda olduklar davranış biçimleri ve kuralları, aktöre, sağtöre” (Türkçe Sözlük, 43) olarak tanımlanmaktadır. Ayrıca Topçu'ya gore ahlak, sadece sistemin bir parçası olmaktan ibaret değildir. Çünkü onun düşünce sisteminde, insan varlı̆̆, bir ahlak varlığı ve ahlak kişisi, toplum ise bir ahlak toplumu, devlet, bir ahlak devleti nihayet insanlı da ahlak bağlamında inşa edilmesi gereken bir tasartm olmaktadır (Akt. Cihan, 2016: 1388). Öyleyse Topçu'nun topluma/toplum yapısına ilişkin sorunları ele alış biçimindeki temel kaygı ahlaktır, denebilir. Onun ahlak sahasındaki amacı ise, ahlak problemini evrensel ölçüler içerisinde çözümlemektir. Çünkü ona göre, evrensel ölçüye uymayan her ahlak görüşü eksiktir (Gündoğan, 2000: 99). Bu bağlamda Topçu (1995: 27) "Evrensel nizamın dışında gerçek ahlakhllk yoktur... Hareketlerini evrensel ölçüye vurarak ve kendi hareketinde evreni kucaklayarak orada kendi şuurunu araması, işte insanın ahlakl davranışı bu şekilde olmahdır" şeklinde bir standart belirleme gayretindedir.
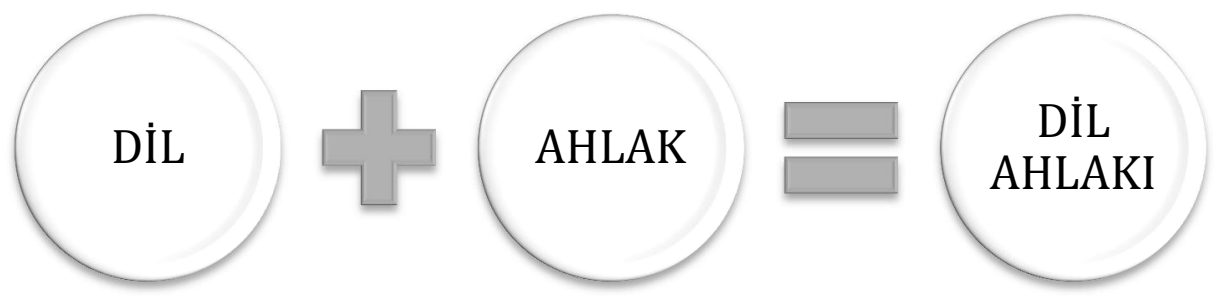

Dil ve ahlak bu çerçevelerden ele alındığında dil ahlakı kavramını şu şekilde tanımlamak mümkündür. Dil ahlakı, insanın dil becerilerini temel ahlak ve örf kurallarına uygun şekilde kullanmasıdır. Dildeki ahlak normları her toplumun kendi değer yargıları ekseninde oluşur, şekillenir. Çünkü ahlak ve ahlaksızhk, mutlaka bir insanın başka insanlar üzerinde yaptığ istenen ve istenmeyen etkilere denir (Topçu, 2005: 13-16). Bu nedenle insanın kendi kendisine karşı ahlaklı veya ahlaksız olabileceği düşünülemez. Bu değer yargıları toplum içerisinde kendi değerlerini gözeterek kuracağı ilişkiler sürecinde ortaya çımmaktadır. Toplumu oluşturan dinamikleri ele alacak pencereden olaya bakan Güngör şöyle demektedir: "Ahlak olmazsa, toplum hayatı denen şey de olmaz, yani insanlar bir arada yaşayamazlar. İnsanlar hangi durumlarda nasıl davranmalarn gerektiğini bildikleri takdirde, başkalarını nasıl davranacağı hakkında da kuvvetli tahminlerde bulunabilir ve böylece güvenlik duygusu içinde yaşarlar" (2000: 18). Ayrıca "şahsiyet" kavramının içini dolduran Güngör: ahlakın 
bireyi şekillendirmesi, ahlakın bireyde görünür kllnması durumuna şahsiyet demektedir (2000: 1112). Ahlakın sosyal temellerini de sorgulayan Güngör, "utanma, utanç, sıkılma" (Türkçe Sözlük, 888) anlamlarına gelen hicabı ahlakın belkemiği olarak niteler. Hicap duygusunun kaybı ahlakın kaybina, ahlakın kaybr ferdin ve toplumun kaybina sebebiyet verir (Güngör, 2010:39).

\subsection{Sosyal medyada dil ve ahlak}

Sosyal medya internet teknolojilerini kullanarak iletişim kurmayı, bilgi paylaşmayı, içerik üretmeyi sağlayan bir platformdur. Bireylerin internette yazdıkları yazılardan, videolardan, fotoğraflardan ve diğer materyallerden oluşur. Cangin'e göre $(2014,19)$ sosyal medya internetin son ylllarda geliştirdiği teknik buluş ile internet kullanıcılarının çok daha kolay girebileceği, oradaki bilgileri kullanabileceği, paylaşacağı Youtube, Facebook gibi sitelerle kolayca iletişim kuracağı bir platformdur. Günümüz sosyal ve teknolojik gelișmeleri sosyal mecralar içerisindeki en önemli gösteri alanlarının Instagram ve Youtube olduğunu göstermektedir. Bu iki platformda hem amatörler hem de ünlü kişi ya da markalar fotoğraf ve videolarını paylaşabilmekte, ilgi çekici birçok fotoğraf ve videoyu izleyicilerine sunabilmektedir (Kirlk ve Tanriverdi Yllmaz, 2018: 122). Myspace, Facebook, Frendster, Flickr, Twitter, Friendfeed ve Youtube gibi siteler, kullanıcıların o anda ne yaptıklarını, düşündüklerini, çektikleri fotoğrafları ve videolarını paylaşabildikleri sanal ortamlar olarak öne çıkmaktadır. "Artık kullanıcılar geleneksel medyanın kendilerine sunduklarıyla yetinmeyip kendi içeriğini oluşturmaya gereksinim duymaktadırlar" (Büyükşener, 2009: 41). Sosyal medyanın bir diğer ilgi çekici yanı da; sürekli güncellenebilmesi, kolay erişilebilir olması bakımından en ideal ortam olmasıdır. (Öztürk ve Talas, 2015: 102). Her anımızı çepeçevre kuşatan sosyal medya ve uygulamaları, eskiye oranla etkisini arttırmış; düşünme eyleminin sınırları bu istilada azalırken gözetleme, teşhir, popülizmin kapıları ardına kadar açılmıştır. (Oğuzhan, 2015: 11).

Çocukların ve gençlerin internette en çok ilgi gösterdiği sitelerden biri Youtube'dur. Youtube her kesimden insanın kendine yer bulabildiği bir ortamdır. Makyajdan yemeğe, alışverişten geziye, bilimden sanata, dinden teknolojiye kadar birçok alanda binlerce insan profesyonel ya da amatör olarak içerik üretmektedir.

Son yıllarda Youtube'daki çocuk ve genç izleyici sayısı önemli bir artış göstermiştir. Youtube kanalları için içerik üretmek, bir meslek haline gelmiş durumdadır. Bu videolarda kız çocukları için evcilik, makyaj ve el becerisi; erkek çocukları için ise yeni oyuncak ve savaş oyunlarının tanıtımı, ilginç ve şaşırtıcı bilgiler gibi içeriklere yer verilmektedir. Çocuklar bu videoları anne ve babalarının hesaplarından izledikleri için kendi yaş gruplarına uygun olmayan bazı içeriklerle de karşılaşmaktadırlar. Çocukların internet ortamında karşılaştığı videoların çoğunu argo ve küfür içeren videolar oluşturmaktadır. Bu araştırma kapsamında farkındalık oluşturulmak istenilen durum; bu içeriklerde geçen argo ve küfürlerin günümüzde bazı ebeveynler tarafından günlük siradan konuşmalar olarak algılanması ve dil zehirlenmesinin idrakinde olunmamasıdır.

Başta çocuklar ve gençler olmak üzere sosyal paylaşım ağları ve içerik üreticilerinin yayın yaptı̆̆ı Youtube, artık günümüz dünyasında fazlaca kullanılır bir hale gelmiștir. Fakat ne yazık ki; kullanılan bu uygulamalar çocukların rahatça ulaşabileceği ve olumsuz etkilenebileceği içeriklerle dolu bulunmaktadır. Bu tarz içerikleri izleyen çocuklar videolarda kulanılan dilden, hareketlerden ve davranışlardan çokça etkilenmektedir. Yaşamı çeşitli yönlerden değiştiren sosyal medyanın sağladığı 
An overview of language ethics from the slang words framework used by secondary school students / N. Karakuş; M. Ö. Karacaoğlu; M. Keten (pp. 172-191)

kolaylıklar ve olanaklar, olumsuz etkilerinin çoğunlukla göz ardı edilmesine neden olmaktadır. Youtube izleme alışkanlığı yetişkinlerin yanında çocuklarda da gittikçe artmaktadır ve bu alışkanlık bir tür bağımlılığa doğru yol almaktadır. Bu bağımlılıkla mücadele etmek için yeni medya okuryazarlığı eğitimleri verilerek özellikle çocukların Youtube gibi platformların zararlı etkilerinden korunması sağlanmalıdır (Ceran, 2019: 39).

Youtube videolarının çocukların hayatının merkezine yerleştiği, vazgeçilmez bir parçası olduğu, onları hem ailelerinden hem de arkadaşlarından uzaklaştırarak toplumsallaşmalarına engel olduğu aşikârdır. Videolar, hareket, renk ve ses gibi unsurları bir araya getirerek çocukların ilgisini kolaylıkla çekmektedir. Çocukların bu videoları izlemeleri, onları erken yaşlarda kaldırabileceklerinden daha fazla uyarana maruz bırakmaktadır. Araştırmada bu olumsuz gelişmeler göz önünde bulundurularak alt problemler oluşturulmuştur: "Ortaokul öğrencilerinin günlük Türkçeyi kullanımında Yotube videolarının etkisi var mıdır?”

Alt Problemler:

- Ortaokul öğrencileri kendi aralarında konuşurken argo kelime kullanıyor mu? Kendi aralarında konuşurken kullandıkları bu argo kelimelerin çeşidi ve sayısı önceki yıllara göre farklılık göstermekte midir?

- Ortaokul öğrencilerinin günlük Türkçe konuşurken kullandıkları/seçtikleri kelime ve kelime öbekleri göz önünde bulundurulduğunda önceki yıllara göre farklılık göstermekte midir?

- Ortaokul öğrencilerinin en çok izlediği Youtuberların, Youtube videolarında kullandıkları dil Türkçenin iyi örnekleri arasında mıdır? Öğrenciler bu dilden etkilenmekte midir ?

\subsection{Amaç}

Ahlak kavramı ile yola çıkılan çalışmada, dil ahlakı üzerinde durulacak ve ortaokul öğrencilerinin günlük Türkçeyi kullandıkları akran konuşmaları esnasında ne tür argo ve benzeri kelimeler tercih ettiklerinin tespiti yapılmaya çalışlacaktır. Çalışmada öğrencilerin dil kullanımında ahlakî değerlere ne derecede dikkat ettiklerinin veya kullandıkları günlük dilin toplumumuzun ahlak değerlerine ne düzeyde uyduklarının ortaya konması amaçlanmıştır. Araştırma sürecinde öğrenci ve öğretmenlerle yapılan görüşmelerde dilde argo ifadelerin kullanımına yol açan sebepler de sorulmuş ve alınan cevaplardan en çok dikkat çeken ifade olarak "video içerik sağlayıcılarından izlenen videoların argo ve küfür kullanımına neden olduğu” tespit edilmiştir. Bu tespit araştırma sürecine en fazla video içeriği sağlayan Youtube videolarının, bu videolarda geçen argo ve küfürlü sözcüklerin çocuklar üzerinde nasıl bir etki bıraktığı ortaya konulmaya çalışılmıştır. Bu amaçla en çok izlenen dört Youtuberın dörder videosu teker teker izlenmiş ve videolarda geçen argo ve küfürlü kelimeler tespit edilmiştir. Yapılan tespitler arasında; bu videolarda kötü söz ve küfürlerin çocuklar ve gençler tarafından günlük hayatta sık sık kullanıldı̆̆ı sonucu dikkat çekicidir. Bu noktadan hareketle çalışmanın genel amacı dilin kullanımında ahlak normlarına uyumun ve öğrencilerin kendi aralarındaki iletişimde taşıdıkları rahatlı̆̆ın argo/küfür kullanımına yol açıp açmadığının tespiti olarak ifade edilebilir. Bu genel amaca dayalı olarak dil ahlakının okul ve arkadaş ortamındaki görünümüne ışık tutması hedeflenmiştir. Zira öğrencilerin bu ortamda dil ahlakına dikkat etmeleri demek, hemen hemen her ortamda dili millî manevî hassasiyetlere ve ahlakî değerlere uygun kullanmaları demektir. Kendi sosyal çevresi içerisinde en rahat üslubu kullanan kişi, bundan daha resmî olan her ortamda hassasiyetini arttıracaktır. 


\section{4. Önem}

Araştırmanın önemi "eğitim-öğretim" sürecinin "eğitim" kavramına dayanmaktadır. Zira ana dili edinimi süreci ile başlayan dil gelişiminin salt bir beceri edinme süreci olmadığı aynı zamanda bir eğitim olduğu dikkat çekmektedir. Okullarda öğrencilerimize "öğretim" verirken "eğitim” bağlamında onların dili nasıl kullandığı, değerlerimize ve ahlak kıstaslarına ne şekilde riayet ettikleri ortaya konmaya çalışılmıştır. Bu noktada durum tespiti yapıldıktan sonra araştırmaya, öğretmen görüşleri ile devam edilmek istenmiş ve öğretmenlerin nöbet veya teneffüs esnasında öğrencilerinden duydukları argo içerikli kelimelerin tespiti ile çalışmaya başlanmış; öğretmenlerin duymadığı bu tip başka kelimeler olabileceği durumunun tespiti ile çalışma küçük bir saha araştırmasına dönmüştür. Böylelikle öğrencilerden elde edilen veriler de çalışmaya dahil edilmiştir. Araştırmanın içerik incelemesi aşamasında ise öğrencilerin dil kullanımını olumsuz etkileyen Youtube videoları incelenmiş ve bu içeriklerde yer alan argo ve küfür ifadeleri tespit edilmiştir. Videolar bağlamında öğrencilerin olumsuz kavramları edinme süreci ortaya konmaya çalışılmıştır.

Türkçe eğitiminin sadece dil becerileri ve dil bilgisi kurallarından ibaret olmadığı, öğretim programlarında örtük olarak değerler eğitiminin yer aldığı unutulmamalıdır. Bundan hareketle doğru ve etkin bir iletişim kurabilmek, millî ve manevî değerlere dayanan bir ahlak anlayışıyla dil becerilerini geliştirmek bu dersin zımnî amaçları arasında düşünülmelidir. Öyleyse bu çalışma ile ortaokul öğrencilerinin genel anlamda dili, özel anlamda Türkçeyi ahlak normlarına göre kullanması irdelenmiş, bundan sonra yapılacak dil ve iletişim eksenli çalışmalarda ahlak kavramının da gözetilmesi gerektiği öne çıkarılmıştır. Sosyal medya, video ve sanal içeriklerde yer alan/kullanılan dilin Türkçeye verdiği zarar ve argo/küfür kullanımının artması da bu yönde yapılacak çalışmalara kaynaklık ederek alana katkı sağlayacaktır.

\section{Yöntem}

\subsection{Araştırmanın modeli}

Araştırma, nitel yöntemle desenlenen bir çalışmadır. Öğrenci ve öğretmen görüşleri “durum çalışması” olarak derlenmiştir. Çalışma grubu olarak ortaokul öğrencileri ve Türkçe öğretmenlerinin görüşleri alınmıştır. Bir "durum”, genellikle sınırları olan bir oluşumdur. Bir kişi, kuruluş, davranışsal koşullar olay ya da diğer sosyal olgular bir durum olarak kabul edilebilirler (Yin, 2017: 6). Durum çalışması ise, bu sınırlı sistemin çoklu bilgi kaynakları aracılı̆̆ ile detaylı toplanan bilgilerle (Creswell, 2016: 97) derinlemesine betimlenmesi ve incelenmesidir (Merriam, 2018: 40).

Araştırmanın diğer safhasında ise nitel araştırma yöntemlerinden doküman analizi kullanılmıştır. Bu yöntemde araştırılması hedeflenen olgu ya da olaylar hakkında bilgi içeren yazılı materyallerin yanı sıra film, video, video kaydı, resim, fotoğraf gibi görsel ve dijital materyallerin incelenmesi sağlanabilmektedir (Creswell ve Clark, 2007). Bu yöntemle Youtube adlı içerik sağlayıcısında yer alan Berkcan Güven, Danla Biliç, Orkun Işıtmak ve Enes Batur adlı çok izlenen Youtuberlardan rastgele metodla dörder tane video seçilmiş olup hepsi teker teker izlenmiştir. Bu içeriklerde araştırmanınn gerekçesini oluşturan probleme dayalı sorulara cevap aranmış, çeşitli tespitlerde bulunulmuştur. Argo ve kötü sözler tek tek tespit edilmiş ve grafiklerle gösterilmiştir. İçerik analizi ağırlkkl olarak yazılı ve görsel verilerin analiz edilmesinde kullanılan bir yöntemdir (Silverman, 2001; aktaran: Özdemir 2010, 335). Ilk once kategoriler geliştirilmiş, daha sonra incelenen veri setinde bu kategoriler içerisine giren kelime, kelime grupları ve cümleler sayılarak tespitler yapılmıştır. 


\section{2. Çalışma grubu}

Araştırmanın çalışmanın grubunu; öğrenci, öğretmen ve inceleme nesnesi dijital içerik olarak üç kategoride ele almak mümkündür. Öğrenci çalışma grubunu Trabzon ilinde resmî bir ortaokulda 6. ve 7. sınıfta eğitim gören 160 öğrenci oluşturmaktadır. Görüşleri alınan öğretmen çalışma grubu ise Türkiye genelinde muhtelif devlet okullarında görev yapan 15 ortaokul Türkçe öğretmeninden elde edilmiş ve öğretmenlerin tespitleri ile öğrencilerin aktardıkları kıyaslanmıştır. Öğrenciler için çalışma grubu oluştururken tek bir okuldan yeterli sayıda öğrenci bulunabileceği için başka bir okul arayışına girilmemiştir. Ancak Türkçe dersinin TTKB kararlarına göre 5 ve 6. Sinıflarda 6 ders saati, 7 ve 8 . Sınıflarda ise 5 ders saati oluşu yaklaşı 1000 öğrenci mevcudu olan okullarda bile azami 10 Türkçe öğretmeni normunu gerektirmektedir. Bu durum dikkate alınarak daha fazla öğretmenin yer aldığı bir çalışma grubu oluşturma adına Türkiye genelinde muhtelif okullarda görev yapan Türkçe öğretmenleriyle gönüllülük esasına dayalı görüşme gerçekleştirilmiştir. Öğrencilerin kendi aralarında kullandıkları argo ve türevi kelimelerin öğretmenlerden elde edilenlerle örtüştüğü fakat öğretmenlerin tahmin ettiğinden çok daha fazla olduğu elde edilen sonuçlar arasındadır. Araştırmanın sebepleri irdelenirken genel anlamda internet kullanımının özel anlamda ise Youtube videolarının bu duruma etkisi tespit edilmiştir. Bundan hareketle çalışma gruplarından elde edilen/edilecek verileri desteklemek adına belirlenen bazı Youtube video içerikleri inceleme nesnesi olarak seçilmiştir. Bu video içeriklerinde yer alan küfür ve argo kelimeler içerik analizi yöntemiyle incelenmiştir. Araştırmanın öğrenci merkezli olarak yürütülen kısmında tespit edilen sözcükler/sözcük grupları ile bu içeriklerde yer alanlar sözcüklerin birbirleriyle olan benzerliği bu duruma yol açan etkenlerin açlk bir göstergesi olarak ortaya konmuştur.

\subsection{Veri toplama araçları ve verilerin toplanması}

Araştırmanın ilk safhasında durum tespiti yapıldıktan sonra araştırmaya, öğretmen görüşleri ile devam edilmek istenmiş ve öğretmenlerin nöbet veya teneffüs esnasında öğrencilerinden duydukları argo içerikli kelimelerin tespiti ile çalışmaya başlanmış; öğretmenlerin duymadığı bu tip başka kelimeler olabileceği durumunun tespiti ile çalışma küçük bir saha araştırmasına dönmüştür. Böylelikle öğrencilerden elde edilen veriler de çalışmaya dahil edilmiştir. Google Forms ile hazırlanan yarı yapılandırılmış görüşme formu ile öğretmenlerden elektronik ortamda toplanan veriler aşağıdaki sorular etrafında şekillenmiştir. Ayrıca bunlar çalışmanın problem sorularını da teşkil etmektedir:

1. Öğrencilerinizin kendi aralarında konuşurken kullandıkları argo kelimeler var mıdır? Varsa nelerdir?

2. Öğrencilerinizin kendi aralarında konuşurken kullandıkları argo kelimelerin çeşidi ve sayısı önceki yıllara göre kıyasladığınızda ne gibi farklılıklar göstermektedir?

3. Öğrencilerinizin Türkçe konuşurken kullandıkları ve seçtikleri kelime ve kelime öbeklerini göz önünde bulundurarak önceki yıllarla kıyasladığınızda ne gibi farklılıklar görmektesiniz?

Öğrenci ve öğretmen görüşlerinin alınması için araştırmacılar tarafından yarı yapılandırılmış görüşme formu tasarlanmıştır. Türkçe eğitimi uzmanları ve ortaokulda görev yapan Türkçe öğretmenlerinin görüşleri doğrultusunda formlara son şekli verilmiştir. Google Forms aracllığlyla elektronik formata dönüştürülen form gönüllülük esasıyla çalışmaya katkı sağlamak isteyen Türkçe öğretmenlerine uygulanmıştır. Veriler toplanırken etik ilkelere dikkat edilmiş, öğrenci ve öğretmenlerden kişisel bilgi 
talep edilmemiştir. Youtube üzerinden herkese açık olarak erişime sunulan videolardaki sözcüklere dayalı veriler ise tarama yöntemiyle elde edilmiştir. Telif yasalarına riayet etme adına Youtuberların resmî Youtube kanallarındaki videolar izlenmiş, aynı adda olup farklı kanallarda yayımlanan içerikler dikkate alınmamıştır.

\subsection{Verilerin analizi}

Öğrenci ve öğretmen görüşleri ile elde edilen veriler içerik analizi yöntemiyle yorumlanmış, bulgular ise gruplandırılarak aktarılmıştır. Video içeriklerinin analizinde içerikler dinleme ve yazılı metne dönüştürme süreçlerine dayalı olarak analiz edilmiştir. Nitel araştırma sürecinin biçimlendirilmesi ve toplanan verilerin analizinde karşılıklı etkileşim, tümevarıma dayalı yaklaşım ve esneklik ön planda tutulması esastır (Balcı, 2011: 38). Bu gerekçelerden hareketle nitel verilerin analiz edilmesi ve yorumlanması aşaması çeşitlilik, esneklik ve çoklu bakış açısıyla derinlemesine inceleme gerektiren bir süreçtir (Karakuş, 2016: 138). Bu araştırmada nitel verilerin analizi tekniklerinden içerik analizi kullanılmıştır. İçerik analizi "sözel, yazılı veya diğer materyallerin içerdiği mesajı, anlam ve/veya dilbilgisi açısından nesnel ve sistematik olarak sınıflandırma, sayılara dönüştürme ve çıkarımda bulunma yoluyla sosyal gerçeği araştıran bilimsel bir yaklaşımdır" (Tavşancıl ve Aslan, 2001: 22). Ayrıca içerik analizi yalnızca metinler üzerinde kullanılan bir teknik değildir. Öğrenci resimleri gibi görsellerin, televizyon programlarının, çekimlerin incelenmesinde de kullanılabilmektedir (Büyüköztürk vd., 2014: 246).

\subsection{Geçerlik ve güvenirlik}

Araştırmacılar tarafından yapılan veri analizinin güvenirliği sağlamak için elde edilen veriler birbirinden bağımsız iki uzmanın görüşüne sunulmuştur. Uzmanların ve araştırmacıların görüşlere/içeriklere ilişkin yaptıkları değerlendirmelerde görüş birliği tespit edilmiştir. Araştırmacı ve uzmanlar arasındaki görüş birliği ve ayrılıklarının araştırmanın güvenirliği üzerindeki etkisi, Miles ve Huberman'ın (1994: 64) formülünden [Görüş birliği/(Görüş birliği+Görüş ayrıllğı)x10o] yararlanılarak incelenmiştir. Yapılan inceleme sonucunda araştırmacı ve iki uzmanın görüşleri arasındaki uzlaşma (güvenirlik) sırasıyla \%92 ve \%94 olarak bulunmuştur.

\section{Bulgular}

Araştırmada elde edilen bulgular iki kategoride değerlendirilmiştir. Bunlardan ilki "öğretmen ve öğrencilerden elde edilen bulgular" olup bu bölümde öğrencilerin kullandıkları argo, hakaret, beddua sözleri tasnif edilmiştir. Ayrıca öğretmenlerin tespitleri, elektronik görüşme formuna verdikleri cevaplarla belirlenerek aktarılmıştır. Bulguların ikinci bölümünü ise video içeriklerinden elde edilen bulgular oluşturmaktadır. Bu bölümde ise inceleme nesnesi olan videolarda geçen argo, küfür, hakaret ifadeleri grafiklerle somutlaştırılmıştır. Ayrıca bu gibi sözlerin/söz öbeklerinin videolarda kaç kez kullanıldığına da ilgili grafiklerde yer verilmiştir.

\section{1. Öğretmen ve öğrencilerden elde edilen bulgular}

\subsection{1. "Öğgrencilerinizin kendi aralarında konuşurken kullandıkları argo kelimeler var meder? Varsa nelerdir?” araştırma sorusuna yönelik bulgular:}

“Öğrencilerinizin kendi aralarında konuşurken kullandıkları argo kelimeler var mıdır? Varsa nelerdir?” sorusuna dayalı olarak öğretmenlerden toplanan verilerin öğrencilerin kullanımlarındaki 
180 / RumeliDE Journal of Language and Literature Studies 2020.S7 (October)

An overview of language ethics from the slang words framework used by secondary school students / N. Karakuş; M. Ö. Karacaoğlu; M. Keten (pp. 172-191)

sözlerle aynı ve benzer olduğu görülmüş, ek olarak çok daha farklı argo ve argo türevi hakaret içeren sözcük elde edilmiştir. Hakaret amaçlı ve beddua amaçl söylenenler olmak üzere iki başlık altında toplanan veriler şöyledir:

\section{Hakaret Amaciyla Söylenenler}

\begin{tabular}{|c|c|}
\hline adam misin & afkur \\
\hline Allah beyinden almış yüze göze vermiş & Allah'a yakın bana uzak ol \\
\hline Allah'in rahatsızı & anasını laciverde boyadığım \\
\hline anasını varlıkta babasını yoklukta beslediğimin evladı & anneni pazarda gördüm \\
\hline Arap & at ağızlı \\
\hline at arabası & at hirsizı \\
\hline at kafalı & at kafası \\
\hline at yalanı seveyim & atara atar gidere giderrr \\
\hline ayl & ayıpsin \\
\hline aynennn & bebe \\
\hline ben de aynı kafadan istiyorum & ben de o köyden geçtim \\
\hline beni çekemeyen anten taksın & beyin yoksunu \\
\hline beyinsiz & beyni 1999 depreminde kalmış \\
\hline beyni 9o'lı yıllardan kalma & bi sal yaaa \\
\hline bok ye & bok \\
\hline boş insan & boş yapıyon birader \\
\hline boş yapma & caz yapma lan \\
\hline çakalll & çok boş yaptın \\
\hline çüşşşŞ & dalarım sana \\
\hline dangalak & domuz \\
\hline dört göz & ederin neki giderin koysun \\
\hline embesil & enayi \\
\hline eşek herif & eşek \\
\hline eşşoğlu eşek & ezik \\
\hline firıldak & gereksiz \\
\hline geriden gelme zekalı & gerizekalı \\
\hline göt & götüm \\
\hline hakiki mal & hareketlere bak, insan taklidi yap bari \\
\hline hayvan & immoral \\
\hline işine bak & it oğlu it \\
\hline kafasına tükürmüşler & kanka laf sokma \\
\hline kap salak & kapaaaak \\
\hline $\begin{array}{l}\text { Karlos'a söyle biraz gezdirsin seni (Karlos: okulun } \\
\text { köpeği) }\end{array}$ & Kars kaşarı \\
\hline kaşar & keko musun? \\
\hline
\end{tabular}




\begin{tabular}{|c|c|}
\hline kelek & keltoş \\
\hline kepçük & kezban \\
\hline klavye kafa & köpek \\
\hline kudur & kuş beyinli \\
\hline kuş kafalı & laf sokacaktım ama sokacak yerin kalmamış \\
\hline laf sokarım derinden aklın oynar yerinden & lale \\
\hline lanet serseri & maço \\
\hline madafon öküzü & mal \\
\hline mal misin & malak \\
\hline malın oğlu & mandafol beyinli \\
\hline maymun bile senden daha zekidir & maymun suratlı şempanze \\
\hline maymun & minority \\
\hline muşmula suratlı, & mutasyon geçirmiş Afrodit \\
\hline neyin kafası bu yaaa & ohaaaa \\
\hline oksijen israfı & orrr....man \\
\hline öküz & özürlü \\
\hline ponçiğim & rahatsiz \\
\hline sakat & salak \\
\hline salça olma & saman ye \\
\hline sana çok pis yükseldim & sarı tavuk \\
\hline sen geri ben ileri zekalı & sen kim köpek \\
\hline seni mayın tarlasına yatırıp bombalarım & senin gibi mal pazarda yok \\
\hline sığır & sözlük beyinli \\
\hline sülale aptalı & şerefsiz \\
\hline şizofren & terledin mi? ortalık kaşar kokuyor \\
\hline tipe bak eldivenle sevilmez & tipsiz \\
\hline tokmak kafa & top \\
\hline turrek & uşak \\
\hline velet & yalan valla \\
\hline yavşak & yol al \\
\hline yollu & zimbo \\
\hline
\end{tabular}

Tablo.1 Öğrencilerin hakaret amacıyla söyledikleri sözler

Tablo.1 incelendiğinde öğrencilerin hakaret amaçlı söyledikleri 130 söz/söz öbeği tespit edilmiştir. Bu sözlerde dikkat çeken en önemli husus öğrencilerin sınıf/okul arkadaşlı̆̆ı yaptıkları kişilere ahlakî değerlerimize sığmayan bu sözleri çok kolay bir şekilde sarf edebilmeleridir. Zira öğrenciler günlük iletişimlerini kurarken en basit bir durumda bile bu sözcüklere başvurabilmektedirler. Öğrencilerin kullandığı bu sözlerin millî manevî değerlerimizle uyuşmayan, karşıdaki kişiyi rencide edici, kişilik haklarına ve fiziksel özelliklere hakaret içeren sözler olduğu belirlenmiştir. Öğrencilerin "eşşoğlu eşek, malın oğlu, it oğlu it, sülale aptalı" gibi sözleri kullanırken karşıdaki kişinin ailesine varacak kadar hakaretler kullandığı tespit edilmiştir. Ayrıca toplumsal anlamda bizi derinden yaralayan 17 A $\breve{g} u s t o s$ 
1999 - Gölcük Depremi gibi bir afetin "beyni 1999 depreminde kalmış” şeklinde argo kullanımında karşımıza çıkması dil ahlakının ne denli gerekli olduğunun bir göstergesidir. Sosyal duyarlılık gösterilmesi gereken bir durumun hakarete vesile kılınması toplum vicdanını yaralayıcı bir durumdur.

\begin{tabular}{|l|}
\hline Beddua Amacıyla Söylenenler \\
\hline Allah belanı versin \\
\hline Allah cezanı versin en yakın zamanda söz selanı ben okucam \\
\hline Allah seni kahretsin \\
\hline Allah tependen batsın \\
\hline ayakkabın yırtılsın \\
\hline evini su bassın \\
\hline evlendiğin ilk gece eşin seni makyajsız görüp boşasın inşallah \\
\hline hapşurasın gelir hapşuramazsın inşallah amin \\
\hline herkesin içinde rezil ol inşallah \\
\hline inşallah yüzündeki kaz ayakları artsın \\
\hline kaşsız kalasın \\
\hline kirpiksiz kal \\
\hline kuaför saçını eğri kessin \\
\hline saçının en güzel olduğu gün saçın bozulsun inşallah \\
\hline tokan kopsun \\
\hline topuğun kırılır inşallah \\
\hline topuklu ayakkabı ayağını vursun \\
\hline yeni aldığın çorapla ıslak yere basasın \\
\hline
\end{tabular}

Tablo.2 Öğrencilerin beddua amaciyla söyledikleri sözler

Tablo.2 incelendiğinde öğrencilerin beddua amacıyla kullandığı 18 söz/söz öbeği tespit edilmiştir. “Kaşsız kalasın, kirpiksiz kal, inşallah yüzündeki kaz ayakları artsın” gibi ifadelerde fiziksel görünüm ve bedenle ilgili hakaretler yer alırken "tokan kopsun, topuğun kurılır inşallah, topuklu ayakkabı ayağın vursun, ayakkabın yırtılsın” gibi ifadelerde kıyafet, aksesuar gibi eşyalara yönelik beddualar yer almıştır. Bunların dışında ise "Allah belanı versin, Allah seni kahretsin" gibi ağır beddualar da bulunmaktadır.

\subsection{2. Öğrencilerinizin kendi aralarında konuşurken kullandıkları argo kelimelerin çeşidi ve sayısı önceki yıllara göre kuyasladığınızda ne gibi farkhlıklar göstermektedir?” araşturma sorusuna yönelik bulgular:}

“Öğrencilerinizin kendi aralarında konuşurken kullandıkları argo kelimelerin çeşidi ve sayısı önceki yıllara göre kıyasladığınızda ne gibi farkllıklar göstermektedir?” sorusuna göre öğretmen görüşleri alınmış ve bulgular şu şekilde ortaya konmuştur:

- $\quad$ Argo kelime sayısı daha fazla. (Ö1)

- Kendi yaşadığım dönemde ve ilk öğretmenlik yaptığım dönemde klasik argo kelimeler duyuyorken şimdilerde daha çok uydurma bir argonun hâkim olduğunu görüyorum. Zaman zaman öğrencilere “O, ne demek ?” diye sorduğum da oluyor. (Ö2) 
- Sınıf öğretmenliği yaptı̆̆ım sınıfta öğrencilerin kendi aralarında kurduğu Whatsapp grubundaki konuşma ve küfürleşmeler beni hayrete düşürdü. Duyduğumda kıpkırmızı kesildiğim sözcükleri çok rahat bir şekilde kullanıyorlar. Önceden böyle şeylerle hiç karşlaşmazdık. (Ö8)

- Mizah ve zeka içeren sözlerden ziyade tamamen uydurma, bel altı, saçma ve kaba sözler kullanıldığını görüyorum. (Ö11)

- İlgi çekme adına yüksek sesle bu sözleri kullanmaları; çevrelerinde bir büyükleri, öğretmenleri varken bile bunların duyulabilme ihtimalinden çekinmemeleri beni çok üzüyor. Genel anlamda hep aynı sözler, Youtube videolarının bunda büyük etkisi var. (Ö13)

- Sosyal medyanın argo kullanımını arttırdığını düşünüyorum. Bazı sözcükler bende hayretler uyandırıyor. (Ö15)

\subsection{3. “Öğrencilerinizin Türkçe konuşurken kullandıklarn ve seçtikleri kelime ve kelime öbeklerini göz önünde bulundurarak önceki yıllarla kuyasladiğınzzda ne gibi farkhhklar görmektesiniz?" araşturma sorusuna yönelik bulgular:}

"Öğrencilerinizin Türkçe konuşurken kullandıkları ve seçtikleri kelime ve kelime öbeklerini göz önünde bulundurarak önceki yıllarla kıyasladığımızda ne gibi farklılılar görmektesiniz?” sorusuna bağlı olarak öğrencilerin hazırlıklı ve hazırlıksız konuşmalarda kendilerini ifade etmelerine dayalı bulgular şöyledir:

1. İstanbul'da on üç ylldır çalışan bir Türkçe öğretmeniyim. Mesleğe ilk başladığım dönemden bu yana daha kötü bir Türkçe var. (Ö3)

2. Cümleler daha kısa, kullandıkları sözcük sayısı az.(Ö4)

3. Yabancı kökenli kelimelerin sayısı oldukça fazla. Kelimenin Türkçe kullanımı yaygın olsa bile yabancı olan tercih ediliyor.(Ö5)

4. Sosyal medya içerikli konuşma ve espriler çok fazla.(Ö6)

5. Var olan cümle yapısını bozarak konuşma artıyor.(Ö7)

6. Gözlemlerimden birisi de ailenin sosyal statüsünün dil kullanımı doğrudan etkilediğidir. (Ö11)

7. 2004 yllından beri Türkçe öğretmenliği yapıyorum. Mesleğimin ilk yıllarında öğrencilerimin argo ve küfür kullanımının daha az olduğunu söyleyebilirim. Taşrada ve köylerde de çalıştım. Oralarda daha fazla küfür kullanıldığını ifade edebilirim. (Öı)

\subsection{Youtube videolarindan elde edilen bulgular}

3.2.1. Berkcan Güven'in dört videosunda geçen argo ve küfürlü kelimeler: Grafik.1'de de görüldüğü üzere Berkcan Güven’in "Reynmen ile Kardeşleri Değisştirdik" isimli on altı dakika on dört saniyelik, "Hesap Kimde ft. Kafalar (50oo TL'lik Alş̧veriş)" isimli on beş dakika otuz dört saniyelik, "Bir Gün Boyunca Hayır Dememek ft. Reynmen (Telefonumu Kirdı)" isimli on yedi dakika elli bir saniyelik ve "Furkan'a Saç Boyama Şakası Tüy Dökücü Krem! Hepimiz Kel Olduk!” isimli on bir dakika üç saniyelik videolar izlenmiştir. 


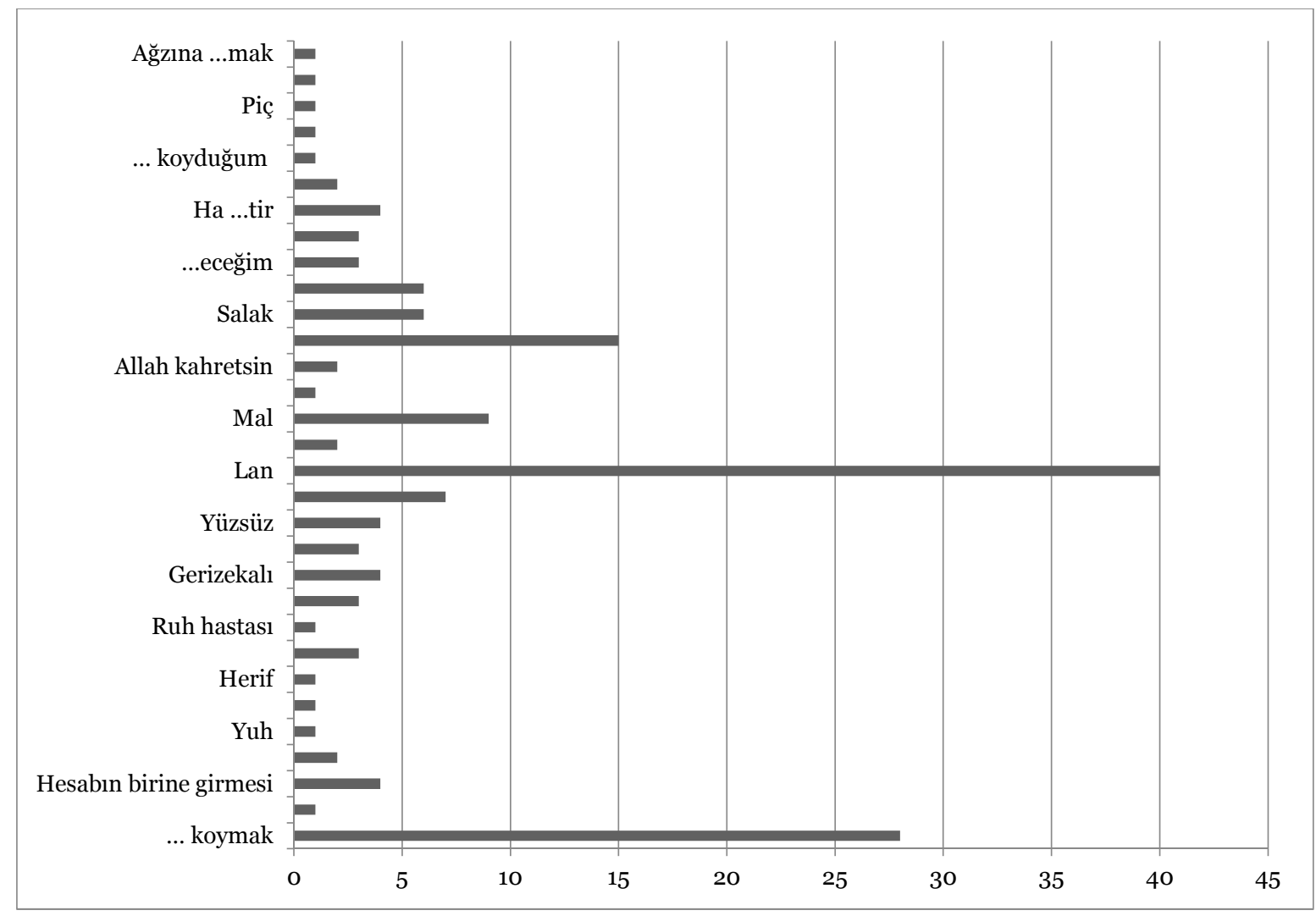

Grafik.1 "Reynmen ile Kardeşleri Değiştirdik”, “Hesap Kimde ft. Kafalar (500o TL’lik Alışveriş)”, "Bir Gün Boyunca Hayır Dememek ft. Reynmen (Telefonumu Kırdı)” ve "Furkan’a Saç Boyama Şakası Tüy Dökücü Krem! Hepimiz Kel Olduk!" videolarında geçen argo ve küfürlü kelimeler

Videolarda "lan” kelimesi kırk, “... koymak” küfrü yirmi sekiz, “...tir git” küfrü on beş, “mal” kelimesi dokuz, "aptal" kelimesi yedi, "salak" ve "bok" kelimeleri altışar, "gerizekalı" ve "yüzsüz" kelimeleri, "hesabın birine girmesi” tabiri ile "ha ...tir" küfrü dörder, "şerefsiz" ve "karaktersiz" kelimeleri, "Allah belanı versin” cümlesi ile “...eceğim” ve “... koyduğumun salağı” küfürleri üçer, "göt” kelimesi, "boş yapmak" tabiri ile "Allah kahretsin” cümlesi ikişer, "yuh”, "uyuz”, "herif”, "ruh hastası” ve "oha” kelimeleri ile "ecdadın ...mek" küfrü birer kez yer almaktadır.

3.2.2. Danla Biliç’in dört videosunda geçen argo ve küfürlü kelimeler: Grafik.2'de de görüldügü üzere Danla Biliç’in "Kerimcan Durmaz Bana Makyaj Yaptı" isimli yirmi yedi dakika on dokuz saniyelik, "Siber Zorba Makyajı" isimli otuz bir dakika elli sekiz saniyelik, "Irem Derici Bana Makyaj Yaptı!” isimli yirmi iki dakika üç saniyelik ve “Takipçilerimi Stalkladım!” isimli on yedi dakika kırk üç saniyelik videoları izlenmiştir. 


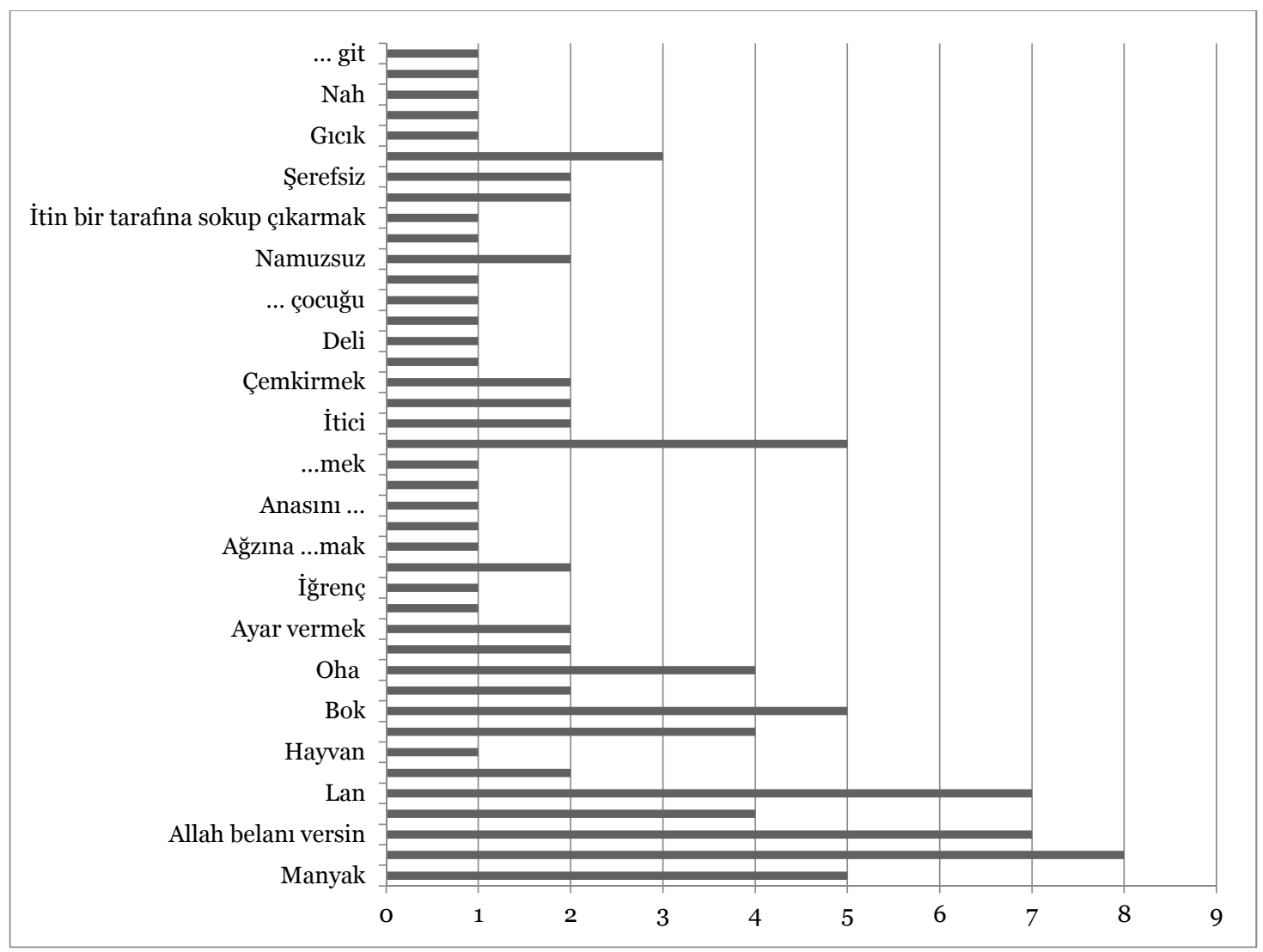

Grafik 2. "Kerimcan Durmaz Bana Makyaj Yaptı”, "Siber Zorba Makyajı”, “İrem Derici Bana Makyaj Yaptı !" ve “Takipçilerimi Stalkladım !” Videolarında Geçen Argo ve Küfürlü Kelimeler

Videolarda "karı" kelimesi sekiz, "lan" kelimesi ile "Allah belanı versin" cümlesi yedişer, "manyak", "bok" ve "kezban" kelimeleri beşer, "gerizekah", "porno" ve "oha” kelimeleri dörder, “... koyayım" küfrü üç, "salak", “dandik”, "goygoy”, "göt”, "itici”, "namuzsuz”, "maymun ağızh” ve "şerefsiz” kelimeleri, "çemkirmek", "birisini yolmak” ve "ayar vermek” tabirleri ikişer, "hayvan”, "sığır", "iğrenç”, "eşek”, “deli”, “cahil”, “gıcık”, "aptal” ve "nah” kelimeleri, “ağzına ...mak”, “anasını ...mek”, "belasını ...mek”, “...mek”, “amq” ve "... çocuğu” küfürleri ile "ağzın yırtmak”, "anan ibretlik” ve "itin bir tarafina sokup çıkarmak" tabirleri birer kez yer almaktadır.

3.2.3. Orkun Işıtmak'ın dört videosunda geçen argo ve küfürlü kelimeler: Grafik.3’te de görüldüğü gibi Orkun Işıtmak'ın "Gece Alsşveriş Merkezinde Kalmak” isimli on altı dakika kırk yedi saniyelik, "Gülümsememe Challenge / $w$ Enes Batur" isimli on üç dakika kırk iki saniyelik, "Yorumlarmızı Canlandırdık! ft. Kafalar, Berkcan" isimli on iki dakika elli dört saniyelik ve “Dünyanın En Kötü Dövmesi” isimli on üç dakika on bir saniyelik videoları izlenmiştir. 


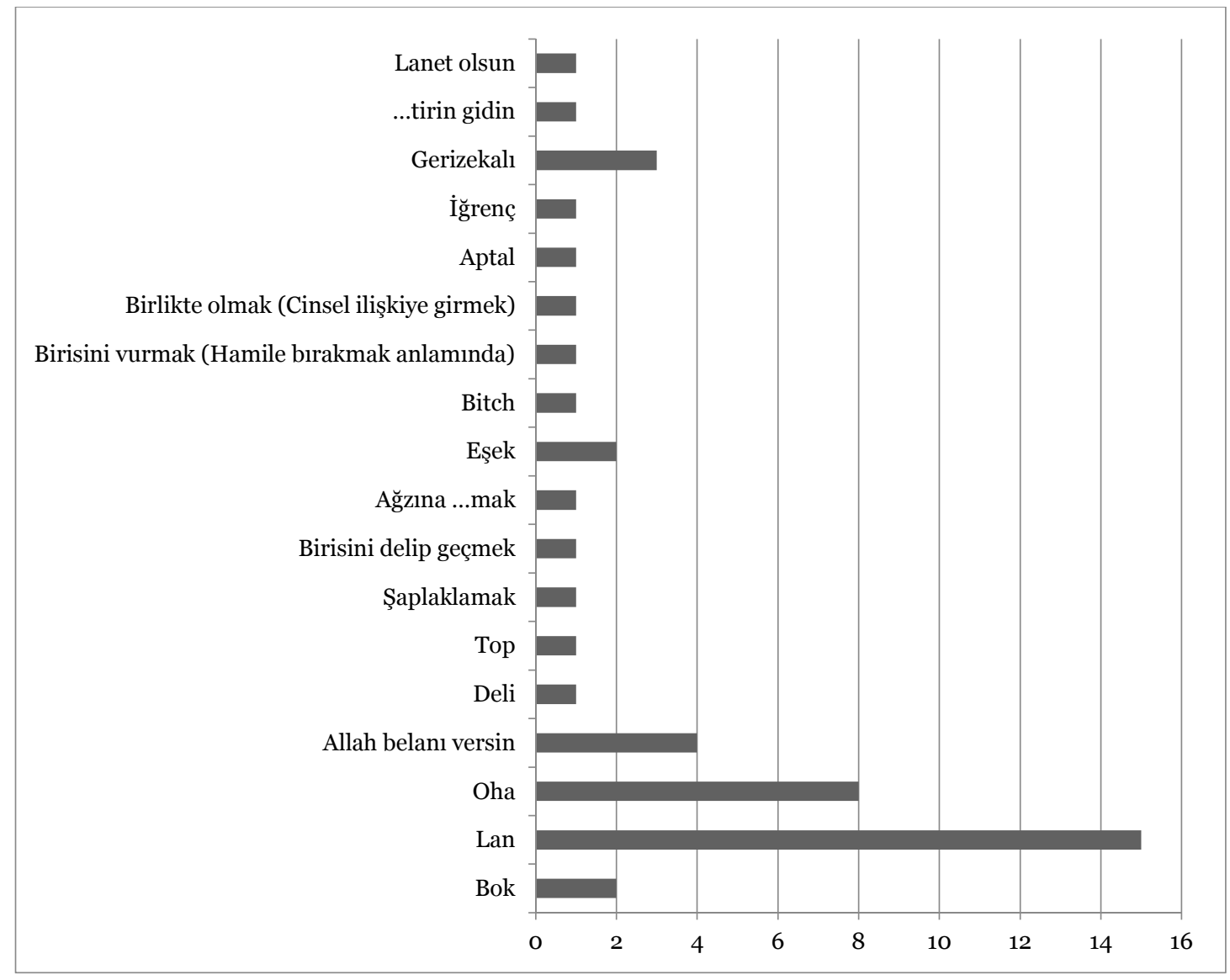

Grafik 3. "Gece Alışveriş Merkezinde Kalmak", "Gülümsememe Challenge / w Enes Batur”, "Yorumlarınızı Canlandırdık! ft. Kafalar, Berkcan” ve “Dünyanın En Kötü Dövmesi” Videolarında Geçen Argo ve Küfürlü Kelimeler

Videolarda "lan" kelimesi on beş, "oha” kelimesi sekiz, "Allah belanı versin” cümlesi dört, "gerizekalı" kelimesi üç, "bok" ve "eşek kelimeleri ikişer, "deli”, "top”, "bitch”, "aptal” ve "iğrenç” kelimeleri, "şaplaklamak", "birisini delip geçmek", "birisini vurmak (hamile bırakmak anlamında)", "birlikte olmak (cinsel ilişkiye girmek anlamında)" tabirleri, “ağzına ...mak” ve “...tirin gidin” küfürleri ile "lanet olsun” cümlesi birer kez geçmektedir.

3.2.4. Enes Batur'un dört videosunda geçen argo ve küfürlü kelimeler: Grafik.4’te de görüldüğü gibi Enes Batur'un "Marketteki Her Şeyi Karıştırıp İçtik" adlı on iki dakika otuz sekiz saniyelik, "En Hızlı Kızak Hangisi? Doğada Kızak Yarışı" isimli on iki dakika kırk iki saniyelik, "Oha Dersen Kaybedersin Challenge!" isimli on yedi dakika elli dört saniyelik ve "En Son Botu Batan Kazanır?! (Sakın Suya Düşme)” isimli on yedi dakika kırk üç saniyelik videoları izlenmiştir. 


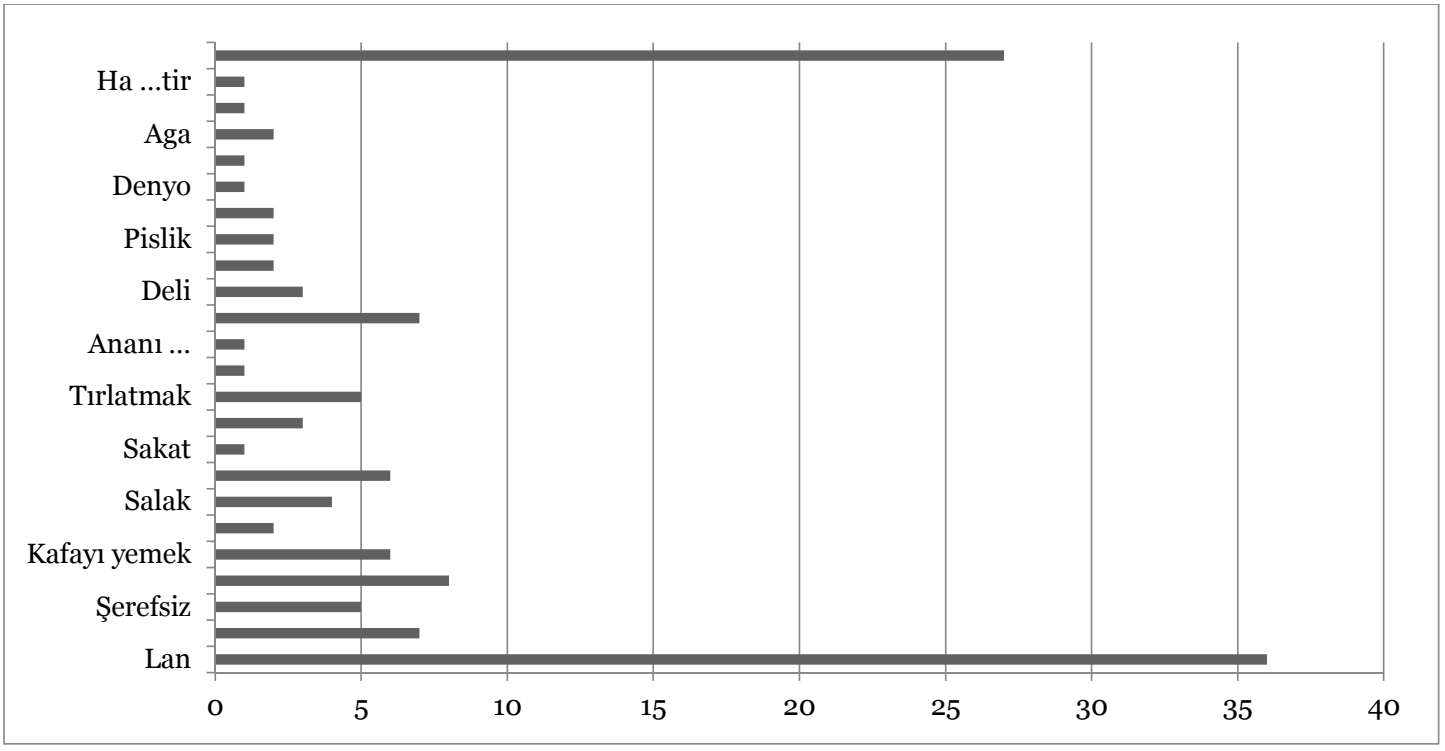

Grafik 4. "Marketteki Her Şeyi Karıştırıp İçtik”, "En Hızlı Kızak Hangisi ? Doğada Kızak Yarışı”, "Oha Dersen Kaybedersin Challenge !” ve "En Son Botu Batan Kazanır?! (Sakın Suya Düşme)” Videolarında Geçen Argo ve Küfürlü Kelimeler

Videolarda "lan" kelimesi otuz alt1, "oha” kelimesi yirmi yedi, "manyak" kelimesi sekiz, "yuh" kelimesi ile "ağzına ...mak" küfrü yedişer, "gerizekal»" kelimesi ile "kafayı yemek" tabiri altı̧̧ar, "şerefsiz" kelimesi ile "trrlatmak" tabiri beşer, "salak" kelimesi dört, "göt" ve "deli” kelimeleri üçer, "dandik", "pislik", "mal" ve "aga" kelimeleri ile "vay anasını" ünlemi ikişer, "sakat", "denyo" ve "rezil" kelimeleri, "ananı ...” ve "ha ...tir" küfürleri, "zlkkımın kökü" tabiri ve "Allah kahretsin” cümlesi birer kez yer almaktadır.

3.2.5. Tüm videolarda en çok geçen argo ve küfürlü kelimeler: Grafik 5 'ten de anlaşllacağı üzere Youtube videolarında argo ve küfürlü kelimeler çekinmeden, cesurca, hiçbir sansür uygulanmadan, rahatça ve başıboş bir biçimde Youtuberlar tarafından kullanılmaktadır. Özellikle "lan", "oha”, “... koyayım”, ... git”, "şerefsiz” ve "ağzına ...mak” tabirleri, çocuklar ve gençler tarafından sanki argo veya küfür değilmiş gibi son derece sıradanlaştırılarak ve normalleştirilerek günlük hayatta sık sık kullanılmakta, neredeyse her cümlenin başına, ortasına veya sonuna ama mutlaka bir yerine eklenmektedir.

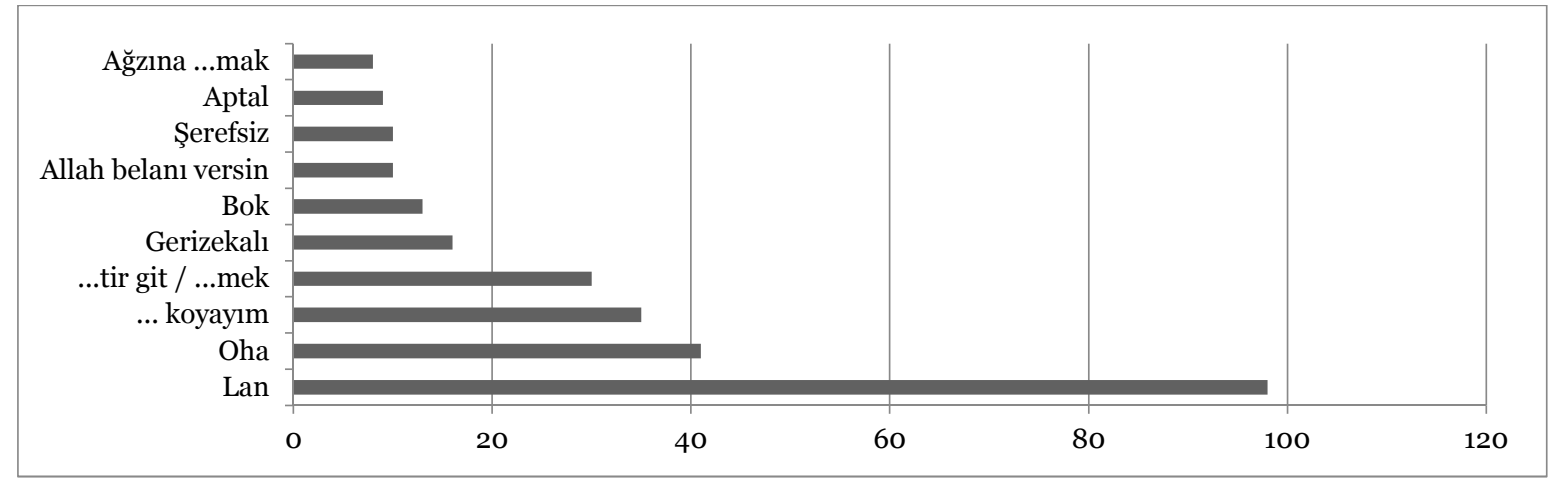

Grafik 5. Tüm Videolarda En Çok Geçen On Kelime ve Cümle 


\section{Sonuç}

Ortaokul öğrencilerinin günlük konuşma dillerinde kullandıkları çok sayıda argo ve türevi kelime tespit edilmiştir. Görüşleri alınan Türkçe öğretmelerinin ifadelerine göre önceki yıllara oranla bu durum her geçen yll artmaktadır. Bu durumun olası nedenleri öğretmenlere sorulduğunda çeşitli cevaplar alınmıştır. Öğretmenlerin verdiği cevaplar analiz edildiğinde hepsinin hemfikir olduğu sonuçlar aşağıda listelenmiştir:

- Öğrenciler, en çok izlenen Youtube kanallarındaki Youtuberların konuşmalarını taklit etmektedir.

- Öğrenciler, sosyal medyanın tesirinde kalmaktadır.

- Öğrenciler, izledikleri televizyon dizilerinin etkisi altında kalmaktadır.

- Öğrenciler, akranlarının ve çevrelerinin etkisi altında kalmaktadır.

- Öğrenciler, kullandıkları argo ve benzeri kelimelerin bazılarının ne anlama geldiğini bilmemektedir.

- Öğrenciler, argo ve hakaret içeren kelimeleri kullanmanın normal bir davranış olduğunu düşünmektedir.

- Öğrenciler, ahlak ve edep sınırları çerçevesinde bu tür kelimelerin kullanılmasının yanlış olduğunu bilmemektedir.

- Öğrenciler, birbiri ile konuşmalarında argo ve benzeri ifadeleri kullanmanın (kendi tabirleri ile) daha havalı olduğunu düşünmektedir.

Yapılan bu araştırmada; öğrencilerin argo kelime ve küfür kullanımında birbirlerinden etkilendikleri kadar Youtube içeriklerinden, sosyal medya, internetten de etkilendikleri sonucuna ulaşılmıştır. Yüz yüze gerçek iletişim yerine yaygınlığı artan sosyal medya, sanal sohbet, kısa mesaj, whatsapp gibi iletişim araçları bu durumu tetiklediği düşünülmektedir. Öğrencilerin bu tip ortamlarda -özellikle kendi aralarnda kurduklar whatsapp gruplarmda- yüz yüze iletişime oranla daha fazla argo ve küfür kullandıkları öğretmen görüşlerinden anlaşılmaktadır. Veli kontrolü olmadığında bu grupların ve Youtube içeriklerinin öncelikle dil ahlakına genel anlamda da ahlakî ve manevî değerlere büyük zarar verdiği ortadadır. Bu zararın boyutları sadece dile değil, toplum ahlak ve değer yargılarına neşet ettiği aileye de yansımaktadır. Teknolojinin gelişmesiyle TV/medya ve bilgisayar/internet kullanımı gittikçe artmakta ve bu durum ebeveyn ile çocuk arasındaki etkileşimi de olumsuz etkilemektedir. Çeşitli araştırmalarda bu teknolojik imkânların iyi değerlendirilemediği veya kontrol altına alınamadığı zamanlarda ortaya çıkan olumsuz tablolar değerlendirilmiştir (Arıcı, 2016: 70). Dil ahlakının çocuk-ebeveyn, öğrenci-öğretmen, usta-çırak etkileşimlerinde ne denli yara aldığı, bunu giderme noktasında yapılabilecekler de başlıbaşına bir çalışma konusu olarak karşımızda durmaktadır.

Özakpınar'a göre (2009: 22) "Bir toplumun üyeleri, davranışlarına yansıyan kültür ve medeniyeti, yeni yetişmekte olan nesillere etkileşim yoluyla geçirir. Bu görgü ve terbiyedir.” Dil ahlakına bu veçheden bakıldığında kadim geleneğimizden gelen donanımla teknolojinin dil ve ahlak olgularımızda vereceği zararı en aza indirme çabası içerisinde olmamız gerektiği aşikardır. Öyleyse bilgi üretme ve 
düşünme biçimlerimizi egemenliği altına alan batılı biliş tarzlarını ve paradigmalarını reddederek, eğitim ve okulu kendi özgün kavramlarımızla düşünmek; evrensel ahlâk ilkeleri üzerine yeniden inşa etmek, hatta insanlık için yeni eğitim modelleri sunmak mecburiyetindeyiz (Turan, 2014: 247). Geçmişimiz, tarihimiz, manen inşa ettiğimiz medeniyet bunu büyük bir sorumluluk olarak biz eğitimcilerin omuzlarına yüklemektedir.

\section{5. Öneriler}

Ortaokul öğrencilerinin görüşleri yanı sıra öğretmen görüşleri ve Youtube videolarının içerik analizi sonucunda ortaokul öğrencilerinin dil ahlakına yönelik bazı öneriler sıralanabilir:

- Model alma davranışı, öğrencilerde karakter oluşumu ve gelişimi üzerinde de etkilidir (Karakuş ve Çoksever, 2019: 47). Bu nedenle öğrenciler, doğru ve düzgün Türkçe kullanan Youtuberlara yönlendirilebilir.

- Öğrenciler, Youtube ve benzeri sosyal medya araçlarını doğru kullanmaya özendirilebilir.

- 21. yüzyl öğrencilerine hitap eden içeriklerde videolar hazırlanabilir ve bu videolarda Türkçenin en güzel şekilde kullanımına dikkat edilmelidir.

- Türkçenin doğru ve güzel kullanımına yönelik yarışmalar düzenlenebilir, bu yarışmaların öğrencileri özendirici nitelikte olmasına dikkat edilmelidir.

- Öğrencilerin kullandıkları argo kelimelerin anlamlarını bilmeleri sağlanarak, ahlak ve edep sınırlarında bu kelimelerin kullanımının doğru olmadığına yönelik bilgilendirmeler yapılabilir.

- Türkçe dersi aynı zamanda millî şuur ve dil bilinci oluşturmanın temelini oluşturan bir derstir (Karacaoğlu, 2019: 1681). Değerler eğitimi içerikleri hazırlanırken dil ahlakı ekseninde çalışmalar yapılabilir. Öğretim programlarında örtük içerik olarak hazırlanacak bu materyallerin sadece Türkçe dersinde değil sosyal bilgiler, din kültürü ve ahlak bilgisi derslerinde de multidisipliner yaklaşımla ele alınması sağlanabilir. Bu konuda Türkçe zümre öğretmenlerinin diğer branş öğretmenleri ile işbirliği içerisinde olması gerekmekte, okul idareleri tarafından gerekli kolaylıklar sağlanmalıdır.

- Turan'ın (2014: 247) ifade ettiği erdemli ve ahlâkl iyi ödev insanı yetiştirme ülküsüu, "millî" eğitim politikalarımızın hedefleri sıralamasında en başta yer almalı ve MEB 2023 vizyonunda bu şekilde kendine yer bulmalıdır. Aksi takdirde Batılı biliş tarzıyla bezenmiş ve her gün muhatap olunan sanal tazyik hem dilimizde hem ahlakımızda hem de "dil ahlakında" büyük bir yara açacaktır.

- Okullarda dil kulübü, münazara kulübü gibi kulüpler aracılığıyla dilin etkin ve güzel kullanımını özendirici çalışmalar yapılabileceği gibi dili ahlak normlarına uygun şekilde kullanan öğrencilerin ödüllendirileceği/teşvik edileceği çalışmalar yürütülebilir. 


\section{Kaynakça}

Arıcı, A. F. (2016). Erken Çocukluk Dil Gelişiminde Ailenin Rolü. Türkiye Eğitim Dergisi, 1(1), 66-78.

Aydoğdu, H. (2009). "Ahlâk Filozofu" ve "Hareket Adamı" Olarak Nurettin Topçu. Atatürk Üniversitesi Türkiyat Araştırmaları Enstitüsü Dergisi, 16(40), 439-462.

Balcı, A. (2011). Sosyal bilimlerde araştırma. Ankara: Pegem A.

Büyüköztürk, Ş., Çakmak Kılıç, E., Akgün, Ö. E., Karadeniz, Ş. ve Demirel, F. (2014). Bilimsel araştırma yöntemleri. Ankara: Pegem A.

Büyükșener, E. (2009). Türkiye'de sosyal ağlarm yeri ve sosyal medyaya bakış. XIV. Türkiye'de İnternet Konferansı Bildirileri, İstanbul, 39-44.

Cangin, S. Ş. (2014). İlköğretim Öğrencilerinin Medya Okuryazarlı̆̆ Dersine Bakış Açıları (AnkaraKeçiören Örneği), Atatürk Üniversitesi Sosyal Bilimler Enstitüsü, Yayımlanmış Yüksek Lisans Tezi, Erzurum.

Ceran, M. (2019). Kültür Endüstrisi Bağlamında Medyanın Kültür Üretim Sürecine Etkisi: Bir Boş Zaman Etkinliği Olarak Youtube, Giresun Üniversitesi Tirebolu İletişim Fakültesi, Bitirme Projesi, Giresun.

Cihan, M. (2016). Nurettin Topçu ve Ahlak Eğitimi. Atatürk Üniversitesi Türkiyat Araştırmaları Enstitüsü Dergisi, (56), 1387-1398.

Creswell, J. W. (2016). Nitel araştırma yöntemleri: beş yaklaşıma göre nitel araştırma ve araştırma deseni. Ankara: Siyasal.

Creswell, J. W., ve Clark, P. (2007). Designingn an conducting mixed method research. USA: Sage Publications.

Gündoğan, A. O. (2014). Ahlak Filozofu Olarak Nurettin Topçu. Türk Dünya Bilgiler Zirvesi: Gönül Sultanlar Buluşması, 225-230.

Güngör, E. (2000). Ahlak psikolojisi ve sosyal ahlak. İstanbul: Ötüken.

Güngör, E. (2010). Değerler Psikolojisi Üzerine Araşttrmalar. İstanbul: Ötüken.

Hocaoğlu, D. (2007). Dil Üzerine Notlar: İnsan'in ve Dil'in Sifir Noktasl; İnsan, Dil ve Cemiyet ve Bir Tipoloji Olarak Aveyronlu Victor. Süleyman Demirel Üniversitesi Fen-Edebiyat Fakültesi Sosyal Bilimler Dergisi, S, 13, 5-36.

Karacaoğlu, M. Ö. (2019). 2023 Eğitim Vizyonu Ekseninde Türkçe Öğretiminde Millî ve Manevî Değerler. UBEST Uluslararası Bilim Eğitim Sanat ve Teknoloji Sempozyumu Bildirileri, 16801684, İzmir.

Karakuş, N. (2016). Maysa ve bulut isimli animasyon çizgi filmin kültürel ögeler açısından incelenmesi/The evalution of the cartoon named maysa and bulut in terms of cultural elements. Mustafa Kemal Üniversitesi Sosyal Bilimler Enstitüsü Dergisi, 13(34).

Karakuş, N. ve Çoksever, P. (2019). Değerler Eğitiminde Rol Model Olarak Kadın Kahramanlar. Eğitim ve İnsani Bilimler Dergisi: Teori ve Uygulama, 10(20), 46-62.

Kırık, A. M., Tanrıverdi Yılmaz B. (2018): Türkiye'de sosyal medya okuryazarlı̆̆ı'nın gerekliliği üzerine bir araştırma. Asos Journal, 6/79 Ekim, 118-142.

Merriam, S. B. (2018). Nitel araşttrma: desen ve uygulama için bir rehber. Ankara: Nobel Akademik.

Oğuzhan, Ö. (2015). “Giriş Niyetine: Sosyal Medya Karnavalında Yamyam Kullanıclar”, (Ed. Özlem Oğuzhan), İletişimde Sosyal Medya Sosyal Medyada Etkileşim. İstanbul: Kalkedon, 11-13.

Özakpınar, Y. (2009). Bir medeniyet teorisi. İstanbul: Ötüken.

Özdemir, M. (2010). Nitel Veri Analizi: Sosyal Bilimlerde Yöntembilim Sorunsah Üzerine Bir Çalş̧ma, Eskişehir Osmangazi Üniversitesi Sosyal Bilimler Dergisi, 11/1, 323-343. 
Öztürk, M. F. ve Talas, M. (2015). Sosyal medya ve eğitim etkileşimi. Zeitschrift für die Welt der Türken, 7(1), 101-120.

Silverman, D. (2001). Interpreting Qualitative Data: Methods for Analysing Talk, Text and Interaction. London: Sage Publication.

Tavşancıl, E. ve Aslan, E. (2001). Sözel, yazıl ve diğer materyaller için içerik analizi ve uygulama örnekleri. İstanbul: Epsilon.

Türkçe Sözlük (2005). Ankara: TDK.

Topçu, N. (2005). Ahlâk. İstanbul: Dergâh.

Turan, S. (2014). Ahlaki açıdan modern okulun açmazı: Eleştirel bir bakış. Yeni Türkiye Dergisi, $10(58)$, 246-252.

Yin, R. K. (2017). Durum çalışması araştırması. Ankara: Nobel Akademik. 